DOI https://doi.org/10.30525/978-9934-26-004-9-130

\title{
ОСОБЛИВОСТІ ФОРМОТВОРЕННЯ ДРАМАТУРГІЇ ХОРОВОГО ТВОРУ «ТЕЧЕ ВОДА В СИНЕ МОРЕ» БОРИСА ЛЯТОШИНСЬКОГО
}

\author{
Регуліч I. B. \\ кандидат мистецтвознавства, \\ завідувач кафедри хорового диригування та постановки голосу \\ Комунального закладу вищої освіти «Луцььий педагогічний коледж» \\ Волинської обласної ради \\ Науменко М. О. \\ викладач хорового диригування \\ Комунального закладу вищої освіти «Луиький педагогічний коледж» \\ Волинської обласної ради \\ м. Луиььк, Украӥна
}

Хорова мініатюра «Тече вода в синє море» на слова Т. Шевченка один 3 найпоетичніших творів Бориса Лятошинського. Композитор використовує весь вірш безсмертного Кобзаря «Думка», в якому змальовуються поневіряння козака в пошуках своєї долі, роздуми про тяжке життя на чужині серед чужих людей, де «ні з ким буде поплакати, ні поговорити».

Вірш знаходить глибоке перевтілення в хорі. «У центрі уваги композитора знаходяться внутрішній світ ліричного героя, його суб'єктивні переживання спрямовані на відтворення «загостреного трагізму буття нації», а не просто фокусуються на символічному сприйнятті дійсності» [2, с. 29]. Образи твору трагічні - зневірений у житті козак, який покинув саме дорого, що в нього було, чужина, море, хвилі якого співзвучні з його переживаннями, а журавлі - символ далекої і недосяжної батьківщини. Саме трагічність являється складовою теми самотності, що притаманна естетиці модернізму та знайшла відображення в музиці Лятошинського [1, с. 13].

Розділи музичної форми базуються на принципах драматургії. Кожна частина об'єднує по два куплети вірша за їх смислом, розвитком сюжету: I частина - експозиція - образ безталанного козака, що їде на чужину шукати долі; II частина - його тяжкі думи і переживання за своїми батьками, коханою дівчиною та марність пошуків щастя; III частина - 
трагічна розв'язка - замість долі «спіткалося горе», «сидить козак на тім боці» і тужить за рідним краєм.

Складна тричастинна форма надає твору «Тече вода в синє море» наскрізний розвиток, що охоплює всю форму в цілому, і приводить до виникнення динамічної репризи. Музичний матеріал розвивається, трансформується, набуває якісно нових рис - від епічно-розповідного до експресивно драматичного характеру. Контраст досягається низкою засобів виразності: тематичний, тембро-фактурний контраст, тональний, ритмічний рух, динаміка, темпи.

Перший розділ витримано в чисто епічній суворій, зосередженій манері розповіді. Одним із найяскравіших засобів художньої виразності в творі є його виразна мелодика, що являє собою цілісне явище, єдність різних сторін - інтонаційно-висотних співвідношень, ритму, динаміки, тембру і штрихів. Драматургія цього твору багата на зміну образів, почуттів і життєвих конфліктів - і все це виражено в головній музичній думці - мелодії.

Уже сам початок хору наближений до розповідної манери співця кобзаря. Широка, епічного складу мелодія басів побудована на двох висхідних квартових ходах i секундових оспівуваннях основного i терцісвого тонів тональності es-moll. Звучання інтервалу зменшеної кварти, утвореного використанням гармонічного мінору (1-2 тактах), вносить трагічний колорит. В другому реченні мелодичну лінію проводить партія тенорів, в той час у басів - контрапункт, побудований на інтонаціях тетрахордів натурального та фрігійського ладів.

В другому періоді першої частини на словах «Пішов козак світ за очі» мелодична лінія змінюється і переходить до партії альтів. Ї̈̈ більш схвильований характер виявляється в гамоподібному русі, пожвавленому ритмічному малюнку, імітаційному розвитку (альт-тенор-сопрано-альт) та прискоренні темпу. Мелодичні фрази імітацій і підголосків об'єднані загальним висхідним рухом, стремлінням до кульмінації I частини на словах «Грає синє море» (8-13 такти). Через співставлення з тональністю as-moll відбувається перехід до другого речення цієї частини. В ній повертається розповідний характер (Тетро I) - заспокоюється ритм, тема проходить в тенорів, обрамлена контрапунктами альтів і басів, остання фраза закінчується октавним унісоном альтів і басів на фоні звучання квінти тенорів (ritenuto) відхиленням в тональність домінанти b-moll.

Друга частина твору за своїм характером драматична. Мелодія першого періоду частини звучить в партії сопрано, ніби від однієї особи. Вона схвильована і імпульсивна, 3 гострим пунктирним ритмом, побудована на квартових інтонаціях. Якщо в I частині вони звучали в 
характері думи, історичної пісні, то тут - це глибокі переживання. Інтонаційний квартовий зворот теми постійно повертається до звуку «es», починається в тональності as-moll i повертається в основну es-moll, ніби ставлячи болюче запитання: «Куди ти йдеш, не спитавшись? < ..> на кого покинув...» [3].

Мелодична кульмінація, що припадає на слова «...батька, неньку старенькую» відзначається переходом теми в більш високий регістр, імітаційними проведеннями іiі мотиву групами жіночих i чоловічих голосів, акцентуванням кожного звуку при динаміці форте. Остання фраза («молоду дівчину») звучить ослаблено, беззахисно, як німе запитання. Цьому сприяє октавний унісон сопрано і тенорів, тиха динаміка, ritenuto.

В другому періоді цієї частини «На чужині не ті люди» (a tempo) тема звучить в різних складах хору. В першому реченні: перша фраза розповідного характеру, проходить в басовій партії в терцію; друга фраза звучить у партії тенорів гострими хроматичними акцентованими інтонаціями в динаміці $m f$, підкреслюючи емоційні переживання героя. Акордово-мелодичний виклад надає звучанню похмурого колориту. У другому реченні знову повертаються «запитальні» інтонації сопрано, але вже тихо і душевно: «ні з ким буде поплакати, ні поговорити». Звучання завмирає, ніби в глибокій задумі, на витриманих акордах pianissimo.

Реприза динамічна і відзначається великою емоційною насиченістю. Вона заснована на контрапунктичному поєднанні остинато, побудованому на інтонаційному зерні головної теми, i нового мелодичного матеріалу. Мотив головної теми, що носив епічнорозповідний характер, повністю перетворюється: багаторазово повторюючись в тональностях es-b-es (баси-тенори-баси), він став мотивом плинності часу, трагічних почуттів і людського життя.

Тема жіночого хору звучить, як плач, голосіння за втраченим молодим життям. Вона розвивається мелодичними ходами в терцію, 3 кожною фразою підіймається у все вищий регістр і в кінці першого періоду досягає мелодичної кульмінації на словах «спіткалося горе». Це - ценеральна кульмінація твору, відзначена високим регістром мелодії, контрапунктичним поєднанням голосів, стрімким crescendo, динамікою $f$ i акцентами.

Щодо теми другого періоду динамічної репризи, то вона розвиває музичний матеріал тужливої пісні жіночого хору. Перші речення першого і другого періодів походять в одному інтонаційному ключі. Друге речення - виразне слово сопрано, мелодична лінія якого побудована на секундових і терцієвих інтонаціях, яке звучить на фоні 
октавного проведення остинато партією басів, що вносить глибокий трагічний колорит. Це - плаче-тужить душа козака, якому нема вороття додому.

Довжинний ритм мелодики цього твору тісно пов'язаний 3 iї розповідним, речитативним характером і відображає інтонації розповіді. Із розвитком драматургії твору з'являються більш активні ритмічні малюнки, які вносять щораз більшу напругу. 3'являється синкопований ритм, який підводить до пунктирного ритму в кульмінації першої частини на словах «грає синє море». Це драматична зав'язка, ніби передбачення нещастя. Імітації пунктирних мотивів, ніби «ламають» долю козака.

В кульмінації другої частини на словах «батька, неньку старенькую» ритм являється одним із засобів художньої виразності - звучить дуже тужливо, широко і наповнено, підкреслений акцентами. На словах «на чужині не ті люди...» мелодика тематичного матеріалу цілком побудована на схвильованому пунктирному ритмі, а в останньому реченні - контрастує із спокійним ритмом підголосків. Короткі акцентовані імітаційні мотиви жіночого і чоловічого складу хору 3 моноритмічним рухом четверних звучать, ніби удари долі. В цих кульмінаціях використані антифонні (без протискладення) імітації, що також сприяють посиленню динаміки драматургії.

В репризі різні ритмічні пласти теми і остинато своїм взаємопроникненням створюють велику динамічну напругу. На фоні пульсуючого ритму остинато звучить широка, емоційно-схвильована мелодія. Закінчується твір ритмічною формулою остинато на тлі тонічного тризвуку, як вічний рух морських хвиль і людських переживань. «Ця фігура повторюється протягом двадцяти восьми тактів. Мабуть, це досі небачене гіперболізоване використання символу трагічного» $[1,16]$.

Виходячи із стилістичних особливостей мелодизму хору «Тече вода в синє море», заснованого на мелосі українських дум, народних та історичних пісень, Б. Лятошинський використовує прийом поліфонічного розвитку музичної тканини, мелодичної багатоплановості. Поліфонічні засоби та їх інтенсифікація надає розробковості, динамізації розділам форми, створює підйом емоційної напруги. Послідовність їх застосування зумовлюється логікою драматичного розвитку твору. Емоційно насичені підголоски сприяють експресивно-динамічному загостренню розвитку теми та допомагають розкриттю образу козака та його душевних переживань. 


\title{
Література:
}

1. Новакович М. О. Канон українського музичного модернізму в творчості Бориса Лятошинського : автореф. дис... канд. мистецтвознавства: 17.00.03. Львів, 2008. 20 с.

2. Рябуха Н. О. Поетика звукового образу світу Б. Лятошинського (на прикладі фортепіанної творчості). Культура Украйни. Вип. 51. Харків, 2015. C. 26-39.

3. Хорові твори на вірші Тараса Шевченка [Ноти] / укл. А. Г. Любченко. Київ, 1989. С. 70-79.

DOI https://doi.org/10.30525/978-9934-26-004-9-131

\section{ВИКОНАВСЬКО-ТЕОРЕТИЧНІ АСПЕКТИ \\ СУЧАСНИХ АЛЬТОВИХ ТВОРІВ (НА ПРИКЛАДІ СОНАТИ ДЛЯ АЛЬТА І ФОРТЕПІАНО № 1 В. БІБІКА)}

\author{
Самокіш М. В. \\ викладач кафедри оркестрових інструментів, \\ аспірантка першого року навчання \\ Комунального вищого навчального закладу \\ «Дніпропетровська академія музики імені Михайла Глінки» \\ Дніпропетровської обласної ради» \\ м. Дніпро, Украӥна
}

У сучасних умовах формування стильових, жанрових, композиційних та виконавських засад музичного мистецтва, важливим постає питання дослідження українських сучасних творів. Насамперед, на нашу думку, це стосується альтового репертуару, що пов'язано $з$ доволі недавньою популярізацією альта у якості солюючого інструмента в порівнянні зі скрипкою та віолончеллю. Бракуванням суто альтових творів призводить до використання альтовими виконавцями репертуару, перекладеного 3 інших інструментів, що, безперечно, не завжди $є$ технологічно зручним для виконання. Невелику кількість праць, присвячених аналізу сучасних альтових українських творів, складають дослідження Косенко Г., Дедюлі Ю., Комлікової А., та інших дослідників.

Актуальність даної теми проглядається крізь призму таких чинників:

- потреба у розширенні альтового репертуару за рахунок українського сучасного репертуару; 